\title{
Brexit and UK-Based Financial Services
}

Le Brexit et les services financiers basés au Royaume-Uni

\section{Nicholas Sowels}

\section{(2) OpenEdition}

\section{Journals}

Electronic version

URL: http://journals.openedition.org/rfcb/1331

DOI: $10.4000 /$ rfcb.1331

ISSN: 2429-4373

\section{Publisher}

CRECIB - Centre de recherche et d'études en civilisation britannique

\section{Electronic reference}

Nicholas Sowels, «Brexit and UK-Based Financial Services », Revue Française de Civilisation Britannique [Online], XXII-2 | 2017, Online since 30 May 2017, connection on 25 November 2019. URL : http:// journals.openedition.org/rfcb/1331; DOI : 10.4000/rfcb.1331

This text was automatically generated on 25 November 2019.

\section{(c) (i) (9)}

Revue française de civilisation britannique est mis à disposition selon les termes de la licence Creative Commons Attribution - Pas d'Utilisation Commerciale - Pas de Modification 4.0 International. 


\title{
Brexit and UK-Based Financial Services
}

\author{
Le Brexit et les services financiers basés au Royaume-Uni
}

\author{
Nicholas Sowels
}

1 Brexit may have a big impact on financial services produced in the United Kingdom, depending on how exactly it unfolds which is almost impossible to predict. London is one of the world's top two leading financial services centres, jockeying year-in, yearout with New York for top place. Its position stems largely from the very high level of international, offshore financial activities operating in the City, and more generally in Britain's capital markets. Taken as a whole, financial services (including insurance \& pensions) contributed $£ 55$ billion in net export earnings to the British economy in 2015, ${ }^{1}$ provide 1.1 million jobs nationwide, and $11 \%$ of tax revenues to the UK government. ${ }^{2}$ Given the place of the City of London in Britain's historical economic model, and that on balance the City and London supported remaining in the $\mathrm{EU}$, it has been noted that the Brexit vote is the first time the City has lost in British political life since the 1930s. ${ }^{3}$

2 Much will depend on how relations between the UK and the EU evolve. Until the start of 2017, the key question concerning the impact of Brexit was linked to whether or not banks and financial services companies operating in the UK would continue to have "passporting" rights to operate throughout the European Union's Single Market. On Tuesday 17 January 2017, however, Theresa May finally ended months of ambiguity about what exactly "Brexit means" by stating that control over immigration and the ending primacy of the European Court of Justice's jurisprudence over UK law would take priority over continued British access to the Single Market. Her speech was followed up by a White Paper published at the end of January 2017 which provided more detail on the Government's position. In principle, banks operating out of the UK will therefore lose such passporting rights. Tellingly, TheCityuk - the key lobbying group for UK-based financial and related services industry - had already dropped its demand that UK-based banks retain passporting, just a few days before Mrs May's speech. ${ }^{4}$ 
3 That said, the British government is still holding out for a bespoke agreement between the UK and the EU, a customised arrangement that will be different from existing agreements the Union has with other, closely associated countries (such as Norway, Switzerland or even Turkey). On the whole, the reactions from Britain's European partners to Mrs May's speech have been fairly consistent, insisting that negotiations cannot begin before the UK notifies its intention to leave under Article 50 of the Treaty on European Union, and stressing that Britain cannot be better-off in its relationship with the rest of Europe, having left "the club".

4 On finance, however, there are concerns in the EU about London and UK-based financial services being shut out of the Single Market. These have not been stated officially, but have leaked out from statements made by Michel Barnier (the EU Commission's Chief Negotiator on Brexit) in January 2017 and a leaked document of the European Parliament (see below). Such concerns are not surprising, given the interconnectedness of global finance and the services which the UK (and London especially) provide to the rest of the European Union. In view of the continuing weaknesses and uncertainties hanging over the world economy and the many unresolved structural problems which global financial markets and banking face, there are indeed good reasons for worrying about the implications of Brexit for the UK and European financial markets. This is especially so if Brexit turns out to be a "cliff edge" break with the EU in spring 2019, when the two-year negotiation period ends, and if no satisfactory exit agreement is established.

At the time of writing the reviewed version of this text (early February 2017), it seems certain that the British government will notify the EU of its intention to leave by the end of March 2017. Other things being equal, this should mean that Britain will leave the Union in spring 2019, before the next European Parliamentary Elections. To be sure, political events may upset this schedule, given the state of flux of British politics and indeed global politics (notably following the election of Donald Trump as President of the United States). The political divisions opened up in the UK by the referendum are far from over, and profound conflicts of interest within the UK show no signs of abating (especially concerning Scotland and Northern Ireland). Similarly, the potential for disagreement between the UK and the EU is considerable, especially concerning Britain's legacy budget obligations to the EU (which could run from anywhere between $€ 20$ billion and $€ 60$ billion), EU migrants' rights, the Government's newly stated wish to remain in the EU customs union yet at the same time negotiate independent trade deals, etc. Even more worrying could be the impression that parts of Britain's political establishment are actively siding with the new Trump administration to encourage the EU to break-up.

6 Given the unpredictable nature of politics now within the UK, and within the wider Western world as a result of the election of Donald Trump, it is impossible to cover all possibilities of how Brexit may now unfold and what it entails for financial services. This article therefore concentrates on what seem today to be the major questions involved in terms of Britain leaving the EU in spring 2019. Section 1 begins by outlining the main characteristics of the UK's financial services and how they operate internationally, as well as the scope of existing EU business. The next section examines what the loss of passporting rights might entail, and sets out some of the key questions concerning an "equivalence" regime. Section 3 then deals with the possibilities of 
transitional arrangements, the dangers of so-called "cliff edge" or "train crash" Brexit, including the risks to the EU were this to occur.

\section{UK-Based Financial Services and the European Union}

7 London is by far Europe's largest financial centre, leading other European centres in a range of services, as shown in Table 1.

Table 1: Financial Markets Share by Country (\%)

\begin{tabular}{|l|l|l|l|l|l|l|l|l|}
\hline & UK & US & Japan & France & Germ. & Sing. & H.K. & Others \\
\hline Cross-border bank lending (Sept 2015) & $\underline{16}$ & 11 & 11 & 8 & 8 & 3 & 4 & 39 \\
\hline Foreign exchange turnover (Apr 2016) & $\underline{37}$ & 19 & 6 & 3 & 2 & 8 & 7 & 18 \\
\hline $\begin{array}{l}\text { Exchange-traded derivatives number of } \\
\text { contracts traded (2014) }\end{array}$ & 6 & $\underline{36}$ & 2 & -- & 10 & - & 1 & 45 \\
\hline $\begin{array}{l}\text { Interest rates OTC derivatives turnover (Apr } \\
\text { 2016) }\end{array}$ & $\underline{39}$ & 41 & 2 & 5 & 1 & 2 & 4 & 6 \\
\hline Marine insurance net premium income (2014) & $\underline{29}$ & 6 & 7 & 4 & 4 & 1 & 1 & 48 \\
\hline $\begin{array}{l}\text { Fund management (as a source of funds, } \\
\text { end-2014) }\end{array}$ & 7 & $\underline{47}$ & 7 & 5 & 4 & -- & 1 & 29 \\
\hline Hedge funds assets (end-2014) & 17 & $\underline{66}$ & 2 & 1 & -- & 1 & 1 & 12 \\
\hline Private equity - investment value (2014) & 7 & $\underline{58}$ & 2 & 3 & 2 & 1 & -- & 27 \\
\hline
\end{tabular}

FIgURES UNDERLINED INDICATE MARKET LEADER.

SOURCE: THECITYUK, THE UK AS AN INTERNATIONAL FINANCIAL CENTRE, NOVEMBER 2016.

8 According to TheCityUK, to give one example, London's strength as a financial centre rests on a whole host of factors, including: an independent regulatory environment; a business climate that facilitates innovation; easy access to international markets; openness to foreign firms (there are over 1,400 financial services firms in the UK that are majority foreign-owned, from around 80 countries); high quality professional and support services, drawing on an impartial legal system based on common law, which tends to be flexible in responding to the development of financial services so that a large proportion of the world's commercial contracts are governed by English law; soft infrastructure, including market infrastructure, the exchanges, data management, telecommunications, and security, and hard infrastructure relating to connectivity, transport and accommodation; a skilled and diversified labour force; a central geographical location between the US and Asian time zones allowing London to work around the clock; English as the local and international language, etc. ${ }^{5}$

These various qualities are widely acknowledged and depend much on the international openness of the UK financial market, which was first tolerated and then 
deliberately encouraged by successive post-war governments. During the 1960s and 1970s, the City began to emerge as an offshore centre for trading in Eurobonds, and subsequently as a hub for US banks escaping domestic regulation. The drive to openness accelerated in the 1980s, with the so-called "Big Bang" which opened up Britain's domestic banking sector to international competition, while further encouraging offshore services to operate in the United Kingdom. This has ensured London a fairly unique development among financial centres, with Helen Thompson, for example, noting that "[n]o one has benefited more for the past three decades from the free movement of capital within advanced economies and the free movement of labour within the EU than the City". ${ }^{6}$

Turning to the UK's role in providing financial services within the EU, Britain as a whole has thus become the Union's lead player in a number of key areas. This is true especially for derivatives trading, foreign exchange trading, hedge fund activity and marine insurance, for which the UK accounts for over half of European business (see Table 2). Overall, it is estimated that $35 \%$ of EU wholesale financial services activity takes place in London.

11 It should also be noted that 112 major European companies are listed on the London stock exchange, because it is a larger, more prominent international market offering better trading and liquidity conditions (i.e. the ease with which investors can enter and exit markets, in this case by buying and selling shares in listed companies). ${ }^{7}$ Furthermore, $60 \%$ of non-EU firms establish their European headquarters in London and the UK, while $40 \%$ of the European headquarters of the top 250 companies are based in London. ${ }^{8}$

Table 2: UK Share of Financial Markets in the EU

\begin{tabular}{|l|l|l|}
\hline & \% share of UK & date \\
\hline Interest rate OTC derivatives trading & 82 & Apr-2016 \\
\hline Foreign exchange trading & 78 & Apr-2016 \\
\hline Hedge funds assets (1) & 85 & 2014 \\
\hline Private equity funds (1) & 49 & 2014 \\
\hline Marine insurance premiums & 65 & 2014 \\
\hline Fund management & 50 & 2014 \\
\hline Equity market capitalisation (LSE) & 30 & 2014 \\
\hline Financial services GDP & 23 & 2014 \\
\hline Bank lending & 26 & 2014 \\
\hline Banks assets (1) & 21 & 2014 \\
\hline Insurance premiums & 22 & 2014 \\
\hline
\end{tabular}




\begin{tabular}{|l|l|l|}
\hline Financial and professional services employment & 15 & 2014 \\
\hline
\end{tabular}

\section{$\%$ SHARE OF EUROPE.}

Source: TheCityUK, The UK as an International Financial Centre, November 2016, based on various sources.

12 Not surprisingly, the UK and London in particular play significant roles in various markets of euro-denominated assets. It is estimated, for example, that UK banks were holding £1.4 trillion in euro-denominated assets at the end of May 2016, while about $40 \%$ of foreign currency denominated loans and deposits in the UK are in euros (equivalent to $17 \%$ of all assets held by UK banks). ${ }^{9}$

13 Average daily euro-denominated foreign exchange turnover in the UK ran to $\$ 930$ billion in April 2013, equivalent to $44 \%$ of estimated worldwide euro-denominated foreign exchange trading: at this level, twice as many euros are traded on the London foreign exchange markets as in all Eurozone countries combined. Liffe - the London International Financial Futures Exchange - is the leading exchange in the trading of short term interest rate derivatives denominated in euro. ${ }^{10}$

14 Turning to the trade figures, the UK exported a total of $£ 88.9$ billion in services to the EU 28 in 2015, including $£ 22.4$ billion in financial services and $£ 3.6$ billion in insurance \& pension services. Total service imports (by Britain from the EU) in the same year were $£ 68$ billion, but only $£ 3.3$ billion were imports in financial services. Thus, the overall surplus on financial services exported to the EU 28 was $£ 22.8$ billion (figures are not available for insurance \& pensions). In terms of the UK's overall current account transactions, the surplus of financial services exported to the EU in 2015 was therefore $25.9 \%$ of the UK's total surplus on trade in services (see Table 3 ). This is quite a substantial contribution to Britain's trade, given that the UK is running quite large current account deficit of about 5\% of GDP (-£100.3 billion).

Table 3: Service Sector Trade by the UK, in 2015

\begin{tabular}{|l|l|}
\hline & In Emillions \\
\hline Exports to the EU 28 & 22,424 \\
Financial services (a) & 3,627 \\
Insurance \& pensions (b) & 3,291 \\
\hline $\begin{array}{l}\text { Imports from the EU 28 } \\
\text { Financial services (c) }\end{array}$ & -- \\
\hline Insurance \& pensions & 88,909 \\
\hline Balance of trade with the EU in financial services and insurance \& pensions (a+b)-c & 22,760 \\
\hline & 67,977 \\
\hline Total service exports to EU & 20,932 \\
\hline Total service imports from EU & \\
\hline Balance on total service trade with EU &
\end{tabular}




\begin{tabular}{|l|l|}
\hline & \\
\hline TOTAL exports of services to world & 50,769 \\
Financial services (d) & 12,907 \\
\hline TOTAL imports of services from world & 8,695 \\
Financial services (f) & 151 \\
\hline Insurance \& pensions (g) & 54,830 \\
\hline TOTAL balance (d+e) - (f+g) & 87,763 \\
\hline & $25.9 \%$ \\
\hline TOTAL balance of UK trade in services & $-100,261$ \\
\hline Share of financial services' surplus in total services surplus, in percent & \\
\hline TOTAL UK current account balance & \\
\hline
\end{tabular}

Source: ONS, Pink Book, 2016, Tables 9.11 and 9.1.

\section{The Major Issues Raised by Brexit for UK-Based Financial Services}

The fundamental issues concerning Brexit and financial services relate to continued access in some form to the Single Market. While there were some discordant voices during the referendum campaign, the dominant view of Britain's financial services industry supported remaining in the EU, in order to have access to financial business throughout the Union. In light of the Brexit vote, the initial general preference was to retain membership of the Single Market, or more specifically to keep so-called "passporting rights" which allow companies based in the UK to provide financial services throughout the EU. For the Government, this of course raised the conundrum of what concessions Britain would have to make to retain such access to the Single Market, once the UK leaves the EU. In particular, these concessions would have involved accepting the four freedoms of the Single Market, and hence continued labour mobility within the Market (i.e. European immigration), and acceptance of EU law.

The likelihood that Government policy would take a different course was, however, already set out clearly by Theresa May in her speech at the Conservative party conference in October 2016, when she clearly stated that her government would take back control over Britain's borders and end the primacy of ECJ law in the UK. With her speech in January 2017 and the subsequent White Paper, these two policy priorities have been very clearly set out, and Britain will therefore leave the Single Market. 


\section{Issues concerning the loss of "passporting" rights} access to the Single Market and the so-called passporting rights. This assumes of course that there is no special or bespoke deal allowing UK financial services to remain in the Single Market. Both the May speech and the White Paper in January 2017 hold out hope for sectoral agreements, as part of a bespoke deal. And as we shall see below, the rest of the EU does indeed have some interest in such a sectoral arrangement for finance. It is therefore not entirely impossible that UK-based financial services will in some way remain within the Single Market, under a sectoral bespoke deal. But at present (February 2017), such continued Single Market access and hence passporting seem like a long bet. In particular, continued membership of the banking and finance sector of the Single Market would mean Britain accepting EU laws and regulations (in finance and related commercial activities), without having any say in how they are made. Alternatively, Britain would still have a direct voice in the shaping of EU financial regulation, even though it has left the Union. These possibilities seem politically highly unlikely and technically complex. But so do the alternatives.

Proponents of leaving the Single Market, or what used to be called "hard Brexit", tend to argue that "passporting" is actually not that important and other business can be generated elsewhere (for example, London can expand its lead role in Islamic banking). However, as with everything else concerning Brexit, the issue of passporting is highly complex. According to the Financial Conduct Authority (the main independent public authority regulating finance, responsible to government and Parliament), there were 5,476 UK-based firms which benefitted from some type of passporting rights to carry out business in other EU countries, in mid-2016. Similarly, there were 8,008 companies based in other EU countries which operate in the UK, on the basis of passporting rights too. But, given the variety of different activities which any one company may carry out, and which may fall under different European regulations, the total number of "outbound" passports held by UK-based companies was 336,421. By contrast, the total number of "inbound" passports (held by firms based elsewhere in the EU and operating in the UK) was only $23,532 .{ }^{11}$ The loss of passporting rights could therefore have consequences for very many businesses.

That said, passporting is not equally important to the main activities undertaken by financial services in the UK. According to the organisation Open Europe (drawing on work by Olivier Wyman Research, a management consultancy), it is above all banking which benefits from passporting, contributing to one fifth of UK-based banking revenues (between $£ 23$ billion to $£ 27$ billion). ${ }^{12}$ Such passporting involves two pieces of EU legislation in particular: the Capital Requirements Directive IV (CRD IV) which relates to retail and wholesale banking (i.e. deposit taking and lending between financial institutions and large entities); and the Markets in Financial Instruments Directive 2 (MiFID II) for investment banking. As CRD IV legislation does not allow for "equivalence" (see below) or meaningful third party access, UK-based banks (such as London-based US wholesale banking establishments) may experience dislocations in their business, if no agreement is reached between the UK and the EU to preserve passporting. ${ }^{13}$ More specifically, Sir Charles Bean (formerly Deputy Governor of the Bank of England and currently Professor of Economics at the London School of Economics) also recently stated to the House of Lords European Union Committee that 
where wholesale financial services need to connect with retail consumers, then the loss of passporting would necessitate setting up subsidiaries in other European countries. ${ }^{14}$ This in turn could entail considerable costs, in terms of opening offices, and providing capital for such independent subsidiaries. ${ }^{15}$

For asset management activities, however, the situation seems to be different. The key EU directives (UCITS and AIFMD) ${ }^{16}$ provide passporting possibilities for funds to be marketed throughout the EU, while operating from a single base. In practice, however, there are several technical barriers to such operations, including: supervisory and legal fees, along with national variations in the definition of 'marketing'. It is therefore difficult in any case for small and medium-sized asset managers to operate across the Union, while larger funds often have local subsidiaries. At the same time, the UCITS and AIFMD directives allow for some portfolio management functions to take place outside the EU, from which UK-based firms could then still benefit after Brexit. As a result, it is estimated that only $7 \%$ of total assets managed in the UK are under direct threat from the loss of passporting rights. ${ }^{17}$

The situation is different again concerning insurance services, which on the whole depend less on European markets: it is estimated that $28 \%$ of insurance service exports went to the EU in 2015 (compared to 44\% for other financial services). This follows from the way insurance continues to be a nationally-based activity, with international companies operating through local subsidiaries, rather than foreign branches. Lloyd's of London, in contrast, operates differently, as an international market, and EU regulations do allow pools of underwriters at Lloyd's to provide insurance throughout the Union. But such work only accounts for $11 \%$ of the market's gross written premium, so it is possible that only as little as $£ 800$ million is directly reliant on passporting. ${ }^{18}$

In short, the loss of passporting rights would surely have quite a significant impact on banks and their business throughout the European Union. But the effects in other financial activities could be much lower. That said, in its report on Brexit: financial services, published in December 2016, the House of Lords Committee on the European Union noted that, "some firms do not themselves appear to be aware of their reliance on the current passporting arrangements", and called for cooperation between firms, the Government and regulators to examine such reliance. ${ }^{19}$

\section{The prospects of "equivalence"}

As UK financial institutions are now most likely to lose passporting rights, attention is shifting to the possibility of operating within the European market, on the basis of socalled regulatory "equivalence". This is a fairly new, open-access regime introduced into EU law in the wake of the financial crisis. It gives access to third-country firms to operate in member states of the European Economic Area (essentially made up of the EU and former EFTA countries like Norway and Iceland), when regulation in their nonEuropean home countries is seen by the EU to have a broadly-equivalent regulatory regime. Such "equivalence" recognition, would allow UK-based financial institutions to operate in the cross border provision of investment services to wholesale clients or counterparties (under MiFID II). London could also remain a venue for trading European shares and so-called over-the-counter (OTC) derivatives: i.e. derivatives on financial assets which are directly traded between parties, and are not carried out through central counterparty clearing houses (CCPs: see below). Other activities that 
may also be covered by equivalence provisions include: the establishment of CCPs; the marketing of Alternative Investment Funds; and Reinsurance activities. ${ }^{20}$

relations between UK-based financial institutions and the European Union, then much will depend on the evolution of such regulations. If things work out well for the UK, exiting the EU could mean that British-based institutions will be able to develop new activities, while remaining within equivalence-accepted regulation, perhaps as part of within the framework of broader international regulatory mechanisms set up after the financial crisis, under the auspices of the $\mathrm{G} 20 .^{22}$ By contrast, it is also possible that future financial regulation in the UK and the EU may diverge, given Britain's clear historical preference for liberalized finance and the more regulatory aspirations of some key European countries (such as Germany and France). In this case, the sale of financial services into Europe by UK-based institutions may well become more difficult and/or costly over time. Much will depend on the kind of overall relationship which the UK will have with the EU in the future. ${ }^{23}$

\section{Transitional arrangements to avoid business falling of a "cliff-edge" in 2019}

\section{Britain's financial eco-system}

According to Olivier Wyman Research, it is important to recognise that the UK's financial sector and allied professional services (in law, accounting, etc.) make up an "eco-system", and that "the effects of the UK's exit from the EU could be felt more widely than simply in business transacted directly with EU clients". In its analysis conducted for TheCityUK, Wyman provides some quantitative forecasts relating to soft and hard Brexit. In the former case, in which the UK is outside the European Economic Area but still has passporting rights and equivalence providing access to the Single Market, the reduction in activity would be modest. The fall in EU-related activity would be about $-€ 2$ billion (equal to roughly $2 \%$ of total international and wholesale business). This drop in output would be accompanied by job losses of 3-4,000, and a fall in tax revenues of less than $£ 500$ million per year. At the other extreme, should the UK's relationship with the EU resort to World Trade Organisation rules, then $40-50 \%$ of EUrelated activity (£18-20 billion in earnings) would be at risk. This in turn would be accompanied by job losses in the order of 31-35,000, and falls in tax revenues of about $£ 5$ billion. ${ }^{24}$

Such forecasts are of course broad figures, and surely much subject to change, depending on the dynamics of how the Brexit process unfolds. Many other factors will likely come into play. Some of these are linked to the question of Brexit itself, for example the impact which new immigration controls and the welcome (or not) given to foreign workers who are highly-skilled and still wanting to work in London. This is where the concept of Britain's financial services industries constituting an "ecosystem" is important. The issue is discussed at quite some length in the House of Lords 
report (see above). The interconnectedness of business activities in finance and related professional services (such as legal services, accounting, information technology, etc.) means that it is very hard to estimate what exactly the effects of losing some activities will be on the eco-system as a whole.

\section{Competition from other European centres and the costs of "hard Brexit" to Europe}

Conversely, the density of the UK-based financial services eco-system with its focus on London may make shifting business elsewhere in Europe quite difficult. To be sure, numerous European financial centres are fishing for business which may leave London. Favourite locations likely to capitalise on Brexit are Dublin (which shares English and common law with London) and Frankfurt (home to the European Central Bank, and perhaps a logical site for the European Banking Authority to relocate to when it leaves London). Paris too is in the running, with Valérie Pécresse announcing in early November 2016 that the Ile-de-France region is setting up a one-stop-shop to help companies move to France..$^{25}$ Greater Paris also has an advantage of being Europe's only other real metropolis, and hence an unparalleled business hub within the EU.

But, a simple switching of locations in Europe may not work out so easily, precisely because no other financial centre in Europe offers anything like the concentration of skills and infrastructure found in London. It is notable, for example, that in October 2016, Jamie Dimon (the CEO of JP Morgan) opined that instead of relocating business elsewhere to Europe, where the infrastructure of financial services is limited, American banks may repatriate work to the New York. ${ }^{26} \mathrm{Mr}$ Dimon also reckoned that Brexit significantly increases the risks of the Eurozone breaking up. This would obviously make other EU centres far less attractive to international financial firms.

Indeed, any dislocation to finance which Brexit could cause is likely to occur as Europe's banking sector is still struggling to emerge from the financial crisis of 2007-2008 and the European sovereign debt crisis at the start of the 2010s. Europe's oldest bank, for example, the Monte dei Paschi di Siena founded in 1472, is regularly in the news with its on-going problems. So too is Deutsche Bank, the German behemoth that has faced difficulties since its massive expansion in the early 2000s. Large French banks too face structural challenges, and are currently reliant on their investment banking activities to earn profits, as large branch networks are costly to maintain. More generally, all of Europe's major banks operate in London, and reorganising their work to take Brexit into account will entail costs, and the probable loss of profitable business.

31 A specific difficulty and its attendant risks concern the central counterparty clearing house (CCP) activities related to transactions in euro-denominated derivatives that are currently booked through London. The CCPs have become more important following the financial crisis, as the G20 agreed on the need for much standardized derivative trading to be transacted through such clearing houses. As a result, risks that were previously born directly by buyers and sellers in direct deals (OTC deals) are hence born by the CCPs, which stand between buyers and sellers, guaranteeing both sides of any transaction. In principle, CCPs can therefore offset risks in any one particular deal because they also clear deals carried out in opposite directions, between very many parties (for example in interest rate swaps or currency trades). The UK is by far 
Europe's largest base for such derivative trading, including in euro-denominated assets. This location is, however, controversial. After all, why should such euro-business take place outside the Eurozone? Indeed, in 2011, the European Central Bank said it would withdraw liquidity support for any CCP dealing above a certain level of eurodenominated transactions outside the Eurozone, thus putting pressure on such activity to migrate to the Eurozone. The UK, however, challenged this decision in the European Court of Justice, and won its case.

With the UK now set to leave the EU, and escape from ECJ rulings, the issue of repatriating the trading of euro-denominated derivations is likely to be reopened and François Hollande has already specifically referred to this. Over time too, the logic of maintaining such trading in a financial centre outside the EU, and hence outside EU law and outside the jurisdiction of the ECB is surely likely to lead to change. But moving from the present situation to setting up similar clearing house capacity elsewhere is potentially fraught with difficult technical and legal problems, and it could destabilise markets. ${ }^{27}$ There are also very likely to be considerable costs related to relocating clearing house activities, while economies of scale available to firms and their clients will likely fall as business is moved out of the massive London markets.

\section{Transitional arrangements to avoid the "cliff-edge"}

Given the complexity of the eco-system, the intricacies of many aspects of international markets, and the ongoing fragility of parts of Europe's banking system and concerns for the global finance system as a whole, there is a good case to be made that Brexit should not prevent continued strong links between the UK and its former EU partners. So there are good arguments for some sort of transitional deal before a final trade and economic agreement is reached between the UK and the EU. The Government's White Paper makes much of the importance the UK to Europe's finance sector and business as a whole: “[o]ver 75 per cent of the EU27's capital market business is conducted through the UK. The UK industry manages $£ 1.2$ trillion of pension and other assets on behalf of European clients. The UK is also responsible for 37 per cent of all European Initial Public Offerings, while the UK receives more than one-third of all venture capital invested in the EU. EU27 firms also have an interest in continuing to serve UK customers". ${ }^{28}$

On the EU side, there have been leaks relating to the awareness of how important Britain's financial services as a whole are to Europe and the Union. In January 2017, it was reported for example that Michel Barnier, the European Commission's Chief Negotiator for Brexit, had told MEPs in a private meeting that "[t]here will be a special/ specific relationship. There will need to be work outside of the negotiation box... in order to avoid instability". Mr Barnier also restated the EU position that there could be no cherry-picking by Britain of parts of the EU it likes, and he did subsequently clarify his comments via Twitter, by referring to "special vigilance" needed concerning finance. Nevertheless, the leak was a clear indication of concerns in Brussels and the EU of Britain dropping out of the Single Market. ${ }^{29}$ (It should be recalled that Michel Barnier was the EU Commissioner responsible for financial market and banking re-regulation in the early 2010s. He should therefore be exceedingly well-briefed on finance.) In a similar vein, in early February 2017, The Guardian published extracts of a leaked report by the European Parliament's economic and monetary affairs committee, pointing out 
that UK-based banks lend more than $£ 1.1$ trillion to other EU member states, and that "[a] badly designed final deal would damage both the UK and the other $27 \mathrm{EU}$ member states" in terms of jobs and growth. ${ }^{30}$

Outsiders too have on the whole backed the importance of moving forward carefully, and avoiding what has been called "train-crash Brexit": i.e. if the UK and the EU fail to reach an agreement between Article 50 notification and the otherwise-automatic exit of the UK from the EU treaties in spring 2019. This scenario would involve existing business relations falling of the "cliff edge", into some sort of legal emptiness, as even establishing a relationship based on the WTO regime requires new legal ratification. During her visit to sound out US banks in New York in September 2016, Wall Street as a whole warned Theresa May that it needs a "long runway" to prepare for Brexit. ${ }^{31}$ Now that the Government has stated very clearly that it is prioritizing control over immigration and ending ECJ jurisprudence over British law, establishing a long runaway will need strong political will and agreement between all parties.

In principle, it is in everyone's interest - Britain's, the EU and even the global financial community as a whole - to manage an ordered transition from the status quo to some sort of post-Brexit arrangement. Yet, events in 2016 have clearly shown up how unpredictable the political evolution of even historically-anchored representative democracies can be. The British Government's current position is paradoxical, to say the least, in wanting to open up the UK economy to even more global trade, and to have a strong European Union as a future partner. But such contradictions pale into insignificance when compared to the tectonic changes that are occurring in the foreign economic relations of the United States since Donald Trump was inaugurated as President on 20 January 2017. Since World War II, the USA has been the main actor and guarantor of the international economy - more or less - based on the rule of law and trade liberalization. Early executive actions by Donald Trump indicate quite clearly that this has now changed: the United States is moving towards a more protectionist and confrontational stance with respect to its historical and new trading partners, as well as with respect to the international institutions and laws that have been built up since 1945. This does not bode well of the degree of international cooperation which emerged after the 2007-2008 financial crisis, in terms of re-regulating finance. In fact, the new Trump administration has already declared that it is seeking to repeal significant aspects of the 2010 Dodd-Frank Act, which applied numerous international guidelines for financial re-regulation to US law. More worrying still, is the way the new US administration has shown itself to be hostile to the European Union. This could well make negotiations between the UK and the EU over Brexit and financial Brexit even more difficult, with potential highly destabilising consequences.

\section{Conclusion}

The 2007-2008 financial crisis and Great Recession led to a prolonged fall in UK living standards. The Coalition government from 2010 to 2015 responded to the ensuing rise in government deficits by making substantial spending cuts, halving the public deficit from about $10 \%$ to $5 \%$. The initial position of the Conservative government elected in 2015 was to press on with this deficit reduction, through spending cuts. In the meantime, while there has been substantial re-regulation of financial services, on balance the structure of banking and international finance has changed little. ${ }^{32}$ At the 
same time, net immigration into the UK (from the EU and from outside the EU) expanded quite strongly, exceeding 300,000 persons per year in the two years before June 2016. It was against this background, that David Cameron held Britain's referendum on whether to leave the European Union.

In the run-up to the referendum, most economic analysts and commentators warned that leaving the EU will be bad for Britain's economy, and could be very costly if the UK loses access to the Single Market. In the event, the aspirations associated with "taking back control" triumphed over what the Leave campaign labelled "project fear", the warnings by the Cameron government and the broader Establishment of the economic fallout from quitting the Union. Since the vote, the dire predictions meted out before the referendum have not come true. Growth in the UK remained buoyant throughout 2016, and financial market turmoil was kept to a minimum, partly thanks to strong, proactive measures by the Bank of England. By contrast, the pound has fallen in value against other currencies by about $15 \%$, compared to the year before the vote. This is leading to a pickup in inflation, which is set to accelerate in the medium term.

Yet it still appears likely that growth may slow down as companies readjust to the strategic decision of the May Government to prioritise immigration control and independence from EU legislation over access to the Single Market. Serious negotiations between the UK and its EU partners will begin, probably towards the end of 2017, once the French and German general elections have taken place. Quite what will happen then is almost impossible to predict. The British government is seeking to negotiate withdrawal from the EU and a new trade relationship in tandem. So far, the EU position is that a withdrawal agreement needs to be negotiated first, before talks can begin on a subsequent trade relationship. Overall, the British position remains one of having one's cake and eating it (as Boris Johnson has said infamously), whereas the UK's European partners are adamant that Britain cannot have a better deal with the "club" once it has left.

The negotiations are going to be politically very tough given the vital interests at stake for both parties. They will also be hideously complex. The negotiations on financial services are an important part of the overall process. They will mirror overall issues concerning the relationship between the UK and the EU, notably concerning some sort of continued access to the Single Market. But at the same time, they surely carry greater risks than negotiations in other sectors. Both parties have an interest in reaching an agreement which minimises damage to the real economy, and certainly both Britain's and Europe's financial institutions will want to pursue as much business as usual. There is also a lot to be said for avoiding big shocks to the financial system, while pursuing further reforms. Banking and finance deserve a lot of the criticism they get. But they are central to how our economies work, so change and reform need to be careful. The problem is that it may just be too difficult to reach agreement on finance in particular and on the UK-EU relationship in general, within the deadlines that now exist.

Text completed 12 February 2017.

Nicholas Sowels is a lecturer in English for economics at the Université Paris 1 Panthéon-Sorbonne. His teaching focuses mainly on the US and UK economies, and his main areas of research relate to public services and the on-going consequences of the financial crisis in 2007-2008. 


\section{BIBLIOGRAPHY}

ALLEN Kate et al., "Wall Street warns Theresa May of need for 'long runway' before Brexit”, The Financial Times, September 21, 2016, <https://www.ft.com/content/ 7099b2e6-7ff9-11e6-8e50-8ec15fb462f4> [7 November 2016].

ARNOLD Martin, "Wall Street bosses warn on Brexit risks", The Financial Times, October 9, 2016, <https://www.ft.com/content/40851fd2-8da5-11e6-a72e-b428cb934b78? ftcamp=published_links\%2Frss\%2Fhome_us\%2Ffeed\%2F\%2Fproduct >, [7 November 2016].

BAILEY Andrew, Letter from Financial Conduct Authority to Committee Chair regarding passporting rights, 17 August 2016, < https://www.parliament.uk/documents/commons-committees/ treasury/Correspondence/AJB-to-Andrew-Tyrie-Passporting.PDF> [8 November 2016].

BARKER, Alex, BRUNSDEN, Jim, "EU reconsiders financial market access rules", The Financial Times, 6 November 2016,< https://www.ft.com/content/838d084ca19d-11e6-86d5-4e36b35c3550,> [7 November 2016].

BOFFEY Daniel, "EU will lose out from bad Brexit deal on City, says leaked report", The Guardian, 2 February 2017, <.https://www.theguardian.com/business/2017/feb/01/eu-brexit-deal-cityleaked-report-european-parliament-article-50 >, [5 February 2017].

HOUSE OF LORDS EUROPEAN UNION COMMITTEE, Brexit: financial services, $9^{\text {th }}$ Report of Session 2016-17, HL Paper 81, published 15 December 2016

DIZARD John, "Clearing houses should not be a bargaining tool in Brexit talks", The Financial Times, July 10, 2016, <https://www.ft.com/content/cddc7964-44f5-11e6-9b66-0712b3873ae1> [7 November 2016].

KING Mervyn, The End of Alchemy: Money, Banking and the Future of the Global Economy, London, Little Brown, 2016.

ONS, Pink Book, 2016, Tables 9.11 and 9.1.

PRIME MINISTER, The United Kingdom's exit from and new partnership with the European Union, presented to Parliament by the Prime Minister, Command of Her Majesty, Cm 9417, February 2017.

RANKIN Jennifer, "EU negotiator wants 'special' deal over access to City post-Brexit", The Guardian, 13 January 2017, <https://www.theguardian.com/business/2017/jan/13/eu-negotiatorwants-special-deal-over-access-to-city-post-brexit>, [5 February 2017].

SCARPETTA Vincenzo, BOOTH, Stephen, How the UK's financial services sector can continue thriving after Brexit, Open Europe, Report 10/2016, Open Europe, 17 October 2016.

STOTHARD Michael, "France one-stop shop seeks post-Brexit business", The Financial Times, November 3, 2016 <https://www.ft.com/content/d0cc8fa8-a1e1-11e6-aa83-bcb58d1d2193>, [7 November 2016].

TheCityUK, Key Facts about UK Financial Service and Related Professional Services, March 2016.

TheCityUK, The UK: Europe's Financial Centre, August 2016.

TheCityUK, Key Facts about the UK as an International Financial Centre, November 2016.

THOMPSON, Helen, "The City Meets Democratic Politics", in Thompson, Helen, Talani, Leila et al. The Impact of Brexit on the City and the British Economic Model, Policy Network and Sheffield Political 
Economy Research Institute, 'Diverging Capitalisms' series, Brief 1, 18 July 2016 <http://

www.policy-network.net/publications_detail.aspx?ID=6120>[4 November 2016].

WYMAN Oliver, “The Impact of the UK's exit from the EU on the UK-based financial services sector", October 2016, < http://www.oliverwyman.com/content/dam/oliver-wyman/global/en/ 2016/oct/Brexit_POV.PDF> [7 November 2016]

\section{NOTES}

1. ONS, Pink Book, 2016, Tables 9.11 and 9.1 (see Table 3 below).

2. Figures based on TheCityUK, Key Facts about UK Financial Service and Related Professional Services, March 2016. The employment figures include: banking $(417,000)$, insurance $(309,000)$, securities $(48,000)$, fund management $(42,000)$ and other services $(245,000)$.

3. THOMPSON, Helen, "The City Meets Democratic Politics", in Thompson, Helen, Talani, Leila et al. The Impact of Brexit on the City and the British Economic Model, Policy Network and Sheffield Political Economy Research Institute, 'Diverging Capitalisms' series, Brief 1, 18 July 2016 <http:// www.policy-network.net/publications_detail.aspx?ID=6120>[4 November 2016].

4. TheCityUK, Brexit and UK-Based financial and related professional services, statement issued 12 January 2017, <https://www.thecityuk.com/research/brexit-and-uk-based-financial-and-relatedprofessional-services/>, [22 January 2017].

5. TheCityUK, Key Facts about the UK as an International Financial Centre, November 2016.

6. THOMPSON, Helen, ibid.

7. TheCityUK, The UK: Europe's Financial Centre, August 2016.

8. TheCityUK, ibid, November 2016.

9. TheCityUK, ibid, August 2016.

10. Ibid.

11. BAILEY Andrew, Letter from Financial Conduct Authority to Committee Chair regarding passporting rights, 17 August 2016, < https://www.parliament.uk/documents/commons-committees/ treasury/Correspondence/AJB-to-Andrew-Tyrie-Passporting.PDF> [8 November 2016].

12. SCARPETTA Vincenzo, BOOTH, Stephen, How the UK's financial services sector can continue thriving after Brexit, Open Europe, Report 10/2016, 17 October 2016.

13. Ibid.

14. BEAN Sir Charles, quoted in HOUSE OF LORDS EUROPEAN UNION COMMITTEE, Brexit: financial services, $9^{\text {th }}$ Report of Session 2016-17, HL Paper 81, published 15 December 2016, paragraph 25.

15. HENLEY Jon, "Brex and the City - Brexit podcast", The Guardian, 27 January 2017, <https:// www.theguardian.com/politics/audio/2017/jan/27/brex-and-the-city-brexit-means-podcast>, [5 February 2017].

16. Respectively the Undertakings for Collective Investment in Transferable Securities Directive and the Alternative Investment Fund Managers Directive.

17. Ibid, SCARPETTA and BOOTH.

18. Ibid.

19. HOUSE OF LORDS EUROPEAN UNION COMMITTEE, Brexit: financial services, $9^{\text {th }}$ Report of Session 2016-17, HL Paper 81, published 15 December 2016, p39.

20. Ibid, para 40.

21. Ibid, paras 41-42.

22. The G20 brings together 19 countries and the EU, covering two thirds of the world's population, $85 \%$ of world trade and $90 \%$ of global GDP. Although it existed before the financial crisis, it came to prominence in the immediate aftermath of the crisis, and played a key role in setting out common approaches to financial re-regulation. Given the early policies adopted by 
President Donald Trump in terms of international relations and his administration's stated aims of unwinding parts of the Dodd-Frank Act (2010) which overhauled US financial regulation, future cooperation within the G20 must now be viewed as uncertain.

23. BARKER, Alex, BRUNSDEN, Jim, "EU reconsiders financial market access rules", The Financial Times, 6 November 2016,< https://www.ft.com/content/838d084ca19d-11e6-86d5-4e36b35c3550,> [7 November 2016].

24. WYMAN Oliver, "The Impact of the UK's exit from the EU on the UK-based financial services sector", October 2016, < http://www.oliverwyman.com/content/dam/oliver-wyman/global/en/ 2016/oct/Brexit_POV.PDF> [7 November 2016].

25. STOTHARD Michael, "France one-stop shop seeks post-Brexit business", The Financial Times, November 3, 2016 <https://www.ft.com/content/d0cc8fa8-a1e1-11e6-aa83-bcb58d1d2193>, [7 November 2016].

26. ARNOLD Martin, "Wall Street bosses warn on Brexit risks", The Financial Times, October 9, 2016, <https://www.ft.com/content/40851fd2-8da5-11e6-a72eb428cb934b78?ftcamp=published_links\%2Frss\%2Fhome_us\%2Ffeed\%2F\%2Fproduct >, [7 November 2016].

27. DIZARD John, "Clearing houses should not be a bargaining tool in Brexit talks", The Financial Times, July 10, 2016, <https://www.ft.com/content/cddc7964-44f5-11e6-9b66-0712b3873ae1> [7 November 2016].

28. PRIME MINISTER, The United Kingdom's exit from and new partnership with the European Union, presented to Parliament by the Prime Minister, Command of Her Majesty, Cm 9417, February 2017.

29. RANKIN Jennifer, "EU negotiator wants 'special' deal over access to City post-Brexit", The Guardian, 13 January 2017, <https://www.theguardian.com/business/2017/jan/13/eu-negotiatorwants-special-deal-over-access-to-city-post-brexit>, [5 February 2017].

30. BOFFEY Daniel, "EU will lose out from bad Brexit deal on City, says leaked report", The Guardian, 2 February 2017, <.https://www.theguardian.com/business/2017/feb/01/ eu-brexit-deal-city-leaked-report-european-parliament-article-50 >, [5 February 2017].

31. ALLEN Kate et al., "Wall Street warns Theresa May of need for 'long runway' before Brexit", The Financial Times, September 21, 2016, <https://www.ft.com/content/ 7099b2e6-7ff9-11e6-8e50-8ec15fb462f4> [7 November 2016].

32. See for example KING Mervyn, The End of Alchemy: Money, Banking and the Future of the Global Economy, London, Little Brown, 2016, pp. 40-41.

\section{ABSTRACTS}

This article seeks to present the key issues which Brexit is raising for financial services based in the UK, as they appeared in early 2017: i.e. since the Government has made clear that Britain will leave both the EU and the Single Market. The article reviews the place of UK-based financial services internationally and with respect to the European Union. The article then looks at some of the main questions currently highlighted by the Brexit process, most notably the loss of "passporting rights" for UK-based banks, and the possibility of "equivalence" status which may allow some firms to continue operating throughout the European Union. The article finishes by 
looking at the dangers involved in so-called "train-crash Brexit" or economic relations with the EU falling off a "cliff edge", if no proper transition process is negotiated by spring 2019. It notes that this could entail considerable risks for the UK and the EU itself, especially as the international environment has become far more uncertain with the election of President Donald Trump.

Cet article cherche à présenter les principaux problèmes que soulève le Brexit pour les services financiers basés au Royaume-Uni, tels qu'ils apparaissent au début de 2017: à savoir depuis que le gouvernement britannique a clairement indiqué que la Grande-Bretagne quittera l'UE et le marché unique. L'article passe en revue la place des services financiers basés au RU à l'échelle internationale et à l'égard de l'Union européenne. Par la suite, l'article examine certaines des principales questions actuellement mises en évidence par le processus du Brexit, notamment la perte de « droits de passeport » pour les banques basées au Royaume-Uni, et la possibilité d'un « statut d'équivalence » qui peut permettre à certaines entreprises de continuer à fonctionner dans toute l'Union européenne. L'article conclut en examinant les dangers de ce que l'on appelle « train-crash Brexit » ou le risque que les relations économiques avec l'UE se précipitent au « bord de la falaise " si aucun processus de transition adéquat n'est négocié d'ici le printemps 2019. L'article note que cela pourrait entraîner des conséquences considérables pour le Royaume-Uni et l'UE elle-même, d'autant plus que l'environnement international est devenu beaucoup plus incertain avec l'élection du président Donald Trump.

\section{INDEX}

Keywords: Brexit, financial services, passporting rights, United Kingdom, European Union

Mots-clés: Brexit, statut d'équivalence, services financiers, droits de passeport, Royaume-Uni, Union européenne

\section{AUTHOR}

\section{NICHOLAS SOWELS}

Université Paris I et CREC Université Paris 3 